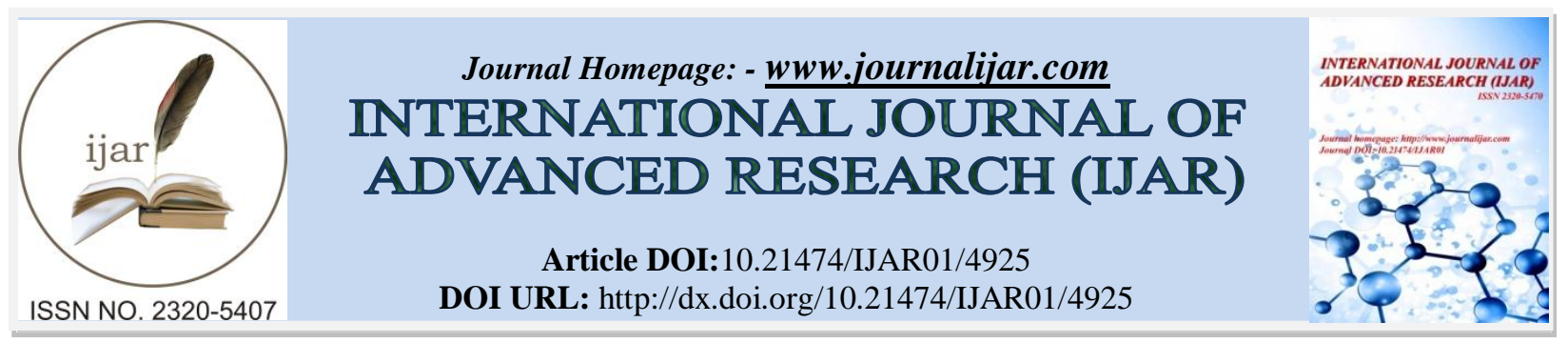

RESEARCH ARTICLE

\title{
STUDY OF THE FLEXURE AND SPILT TENSILE STRENGTH BEHAVIOUR OF STEEL FIBRE REINFORCED CONCRETE USING VARIOUS PERCENTAGE OF STEEL FIBRE.
}

\section{Divanshu seervi $^{1}$, tarun gehlot ${ }^{2}$ and Dr. peeyush chowdhary ${ }^{3}$.}

1. M.E Scholar, Structural Engineering Department MBM Engineering college JNV University Jodhpur, Rajasthan India.

2. M.E Scholar, Structural Engineering Department MBM Engineering college JNV University Jodhpur, Rajasthan India.

3. Associate Professor, Structural Engineering Department MBM Engineering college JNV University Jodhpur Rajasthan India.

\section{Manuscript Info}

Manuscript History

Received: 22 May 2017

Final Accepted: 24 June 2017

Published: July 2017

Key words:-

FRC ,SFRC,UTM , OPC , $\mathrm{F}_{\mathrm{b}}, \mathrm{T}_{\mathrm{SP}}$ ASTM.

\section{Abstract}

Fiber reinforced concrete (FRC) is a new structural material which is gaining increasing importance. Addition of fiber reinforcement in discrete form improves many engineering properties of concrete. The objective of this research investigation was to study the flexure and spilt tensile strength behavior of steel fibre reinforced concrete using Round straight fibres with aspect ratio of 75 Specimens were cast without fibres and with fibres of $0.5 \%, 1 \%, 1.5 \%$ and $2 \%$. split tensile tests and Flexural Strength were conducted on cylinder and beam specimens respectively

Copy Right, IJAR, 2017,. All rights reserved.

\section{Introduction:-}

Fibre-reinforced concrete (FRC) is concrete containing fibrous material which increases its structural integrity. It contains short discrete fibres that are uniformly distributed and randomly oriented. Fibres include steel fibres, glass fibres, synthetic fibres and natural fibres Fibre-reinforced concrete is becoming an increasingly popular construction material due to its improved mechanical properties over unreinforced concrete and its ability to enhance the mechanical performance of conventionally reinforced concrete. Though much research has been performed to identify, investigate, and understand the mechanical traits of fiber-reinforced concrete, relatively little research has concentrated on the transport properties of this material.. When the fibre reinforcement is in the form of short discrete fibres, they act effectively as rigid inclusions in the concrete matrix. Physically, they have thus the same order of magnitude as aggregate inclusions; steel fibre reinforcement cannot therefore be regarded as a direct replacement of longitudinal reinforcement in reinforced and pre stressed structural members. However, because of the inherent material properties of fibre concrete, the presence of fibres in the body of the concrete or the provision of a tensile skin of fibre concrete can be expected to improve the resistance of conventionally reinforced structural members to cracking, deflection and other serviceability conditions. In addition, if concrete casings are uses as shielding containers for pollutants and toxic wastes, permeability is of utmost importance in order to assure that no potentially harmful leakage occurs. Because of the important role played by permeability in structural safety, and the increasing use of fibre-reinforced concrete, this research paper examines the effects of different fibre volumes $(0 \%, 0.5 \%$, and $1 \%)$ of steel fibres in fibre-reinforced beam. It was thought that increasing the volume of steel fibres

Corresponding Author:- Divanshu seervi.

Address:- Structural Engineering Department MBM Engineering college JNV University Jodhpur, 
would decrease the permeability of the cracked specimens due to crack stitching by the steel fibres. fibres do not change material porosity.

\section{Steel Fibre Reinforced Concrete :-}

It is now well established that steel fibre reinforcement offers a solution to the problem of cracking by making concrete tougher and more ductile. It has also been proved by extensive research and field trials carried out over the past three decades, that addition of steel fibres to conventional plain or reinforced and pre stressed concrete members at the time of mixing/production imparts improvements to several properties of concrete, particularly those related to strength, performance and durability. Many types of steel fibres are used for concrete reinforcement. Steel fibres are widely used in civil engineering applications and concrete reinforcement, due to its relative availability, reasonable cost and better experience in its application with conventional steel reinforcement. The composition of steel fibres generally includes carbon steel (or low carbon steel, sometimes with alloying constituents), or stainless steel. Different applications may require different fibre composition. The normal range of aspect ratio for steel fibre is from 20 to 100. Aspect ratio of steel fibre greater than 100 is not recommended, as it will cause inadequate workability, formation of mat in the mix and also non uniform distribution of fibre in the mix. Steel fibres greatly increase toughness of concrete, which primarily is used for crack and shrinkage controls, to serves as secondary reinforcement for pavements, slabs, pipes, channel and tunnels..The steel fibres used in the experiment were obtained from binding steel wires used in tying reinforcement bars. Aspect ratio of the steel fibres was 75 . These wires were properly cut to obtain a length of $6 \mathrm{~cm}$. The diameter of steel fibre was $0.8 \mathrm{~mm}$ and tensile strength of steel fibre is $1500 \mathrm{~N} / \mathrm{mm}^{2}$. Fibre Reinforced Cement' as a material made from hydraulic cement and discrete, discontinuous fibres (containing no aggregate). "Fiber reinforced concrete" (FRC) is made with hydraulic cement, aggregates of various sizes, in corporating discrete, discontinuous fibers. Both are firmly established as a new construction material.The necessity for the addition of fibers in structural material is to increase the strength of the concrete and mortar and also to reduce the crack propagation The steel fiber is known to have possessed high tensile strength and ductility. High strength fibers, favorable orientation large volume, fiber length and diameter of fiber have been found independently to improve the strength of composites. The steel fiber is known to have possessed high tensile strength and ductility.

The main properties of Steel Fibre Reinforced concrete are discussed below.

\section{Toughness:-}

The main reason for incorporating steel fibres in concrete and shotcrete is to impart ductility to an otherwise brittle material. Steel fibre reinforcement improves the energy absorption, impact resistance and crack resistance of concrete. Steel fibre reinforcement enables the concrete to continuously carry load after cracking ,called post crack behaviour variety of tests have been developed to measure and quantify the improvements achievable in steel fibre reinforced concrete.

\section{Durablity:-}

The corrosion resistance of Steel Fibre Reinforced Concrete (SFRC) is governed by the same factors that influence the corrosion resistance of conventionally reinforced concrete. As long as the matrix retains inherent alkalinity and remains un cracked, deterioration of SFRC is not likely to occur. It has been found that good quality SFRC when exposed to atmospheric pollution, chemicals or a marine environment, will only carbonate to a depth of a couple of millimeters over a period of many years. Steel fibre immediate layer of corrode to the depth of surface carbonation, causing some rust colored surface staining. In a trafficked or abrasive exposure environment such corroded surface fibres rapidly wear away and disappear.. There concrete specimens were subjected to accelerated corrosion and it was found that there was no corrosion of steel fibres in SFRC even after 250 cycles of corrosion. Additions of steel fibres in concrete matrix have resulted in decreased crack width. It was also noted that the addition of steel fibres in concrete results in delayed cracking of concrete.

\section{Seismic Resistance:-}

By using SFRC in a beam-column joint, some of the difficulties associated with joint construction can be overcome and a greater seismic strength can be provided. applied to structures. In conventional joints, such energy is dissipated by concrete cracking, steel deformation, steel bending etc. In steel fibrous joints, the goal is to dissipate such energy via progressive fibre pullout from concrete. It was found that the steel fibre reinforced concrete joint had a higher ultimate moment capacity, had better ductility, was stiffer, and was more damage tolerant. 


\section{Shear Resistance:-}

Large earthquakes result in high shear forces within the beam-column joint. To withstand such forces, hoop spacing is decreased within the joint region. This can sometimes result in congestion problems that can result in construction difficulty. SFRC can be used with increased hoop spacing to provide higher shear resistance.

\section{Dynamic Resistance:-}

Dynamic strength of concrete reinforced with various types of fibres subjected to explosive charges, dropped weights and dynamic tensile and compressive load has been measured. The dynamic strength of various types of loading was 5 to 10 times greater for fibre reinforced than for plain concrete. The greater energy requirement to strip or pull-out the fibres provides the impact strength and the resistance to spalling and fragmentation. Steel fibre concrete was found to provide high resistance to the dynamic forces of cavitations under high head, high velocity water flow conditions.

\section{Bar Confinement:-}

Confinement of the rebar in a structure is very important for the performance of the joint in an earthquake. The bond between concrete and rebar is affected by the amount of steel congestion in a joint. If there are a lot of hoops overlapping with small spacing in a joint, then the bond between concrete and rebar can be poor. Poor bond results when there is not enough space between the bars to allow the concrete to pass through. A joint with increased hoop spacing will have better bar confinement, as there will be ample room for the concrete to flow around the bars and to properly bond. However, in a seismic beam-column joint it can be nearly impossible to allow for an increased hoop spacing providing better confinement because the high shearing forces present in a joint require numerous hoops. To remedy this situation, steel fibre concrete can be used in place of some hoops.

\section{Behaviour Of Steel Fibre Reinforced Concrete Under Flexure:-}

In numerous investigations, it has been displayed that the flexure, shear, torsion, punching, dynamic impact behaviors of structural elements improved by the use of Steel Fibre Reinforced Concrete. The positive effects of SFRC on the flexure behavior of the structural elements are given as follows by-

a. Increases moment capacity and cracking moment,

b. Increase the ductility,

c. Increases crack control,

d. Increases rigidity,

e. Preserves the structural integrity after beam exceeds the ultimate load.

\section{Experimental Program:-}

The objective of this research investigation was to study the behavior of Steel Fibre Reinforced Concrete (SFRC). Straight rounded steel fibres with aspect ratio of 75 were used. Specimens were casted without fibres and with fibres of $0.5 \%, 1 \%, 1.5 \%$ and $2 \%$. flexural strength and split tensile tests were conducted on beams and cylinder specimens respectively. A total of 24 cylinders of dimension 300X150 mm and 15 numbers of beam specimen of dimension 500X100X100 mm were casted. The steel fibres used in the experiment were obtained from binding steel wires used in tying reinforcement bars. These wires were properly cut to obtain a length of $6 \mathrm{~cm}$. The diameter of steel fibre was $0.8 \mathrm{~mm}$.

Five types of specimens were prepared and designated as S-0, S-1, S-2, S-3 and S-4.

S-0: Control Concrete containing no fibres (PCC).

S-1: Concrete containing $0.5 \%$ steel fibres by volume of concrete.

$\mathrm{S}-2$ : Concrete containing $1 \%$ steel fibres by volume of concrete.

S-3: Concrete containing $1.5 \%$ steel fibres by volume of concrete.

S-4: Concrete containing $2 \%$ steel fibres by volume of concrete.

\section{Mix Design For M20 Grade Concrete (IS 10262:2009):-}

Proper design of concrete mixture is intended to obtain such proportioning of ingredients which will produce concrete of high durability performance during the designed life of a structure, usually 50 years.

For a particular strength and long term qualities and performance. Several factors determine these properties.

a. Quality of cement.

b. Proportion of cement and other cementations materials in relation to water in the mixture (water/cementation ratio). 
c. Strength and cleanliness of aggregate.

d. Interaction or adhesion between cement paste and aggregate.

e. Adequate mixing of ingredients.

f. Proper placing, finishing, and compaction of fresh concrete.

g. Curing at a temperature not below $50^{\circ} \mathrm{F}$ while the placed concrete gains strength.

h. Chloride content not exceeds $0.15 \%$ in reinforced concrete exposed to chlorides in service and $1 \%$ for dry protected concrete.

A study of these requirements shows that most of the control actions have to be taken prior to placing the fresh concrete. Since each control is governed by the proportion and the mechanical ease or difficulty in handling and placing, the development of criteria based on the theory of proportioning for each mixture should be studied. In addition, a determination has to be made as to the admixtures that need to be prescribed to enhance the long-term high performance and durability of the finished product. There are several types of strength-modifying admixtures: high range water reducers (super plasticizer), polymers, granulated blast furnace slag, fly ash, or slica fume. However, in mixture proportioning for very high strength concrete, isolating the water/cementation materials ratio $\mathrm{W} /(\mathrm{C}+\mathrm{P})$ (often called simply $\mathrm{w} / \mathrm{cm}$ ) from the paste/aggregate ratio due to the very low water content can be more effective in arriving at the optimum mixture with fewer trial mixtures and field trial batches.

\section{Step 1:-Design Stipulations For Proportioning:-}

1. Grade designation: $\mathrm{M} 20$

2. Type of cement: OPC 43 grade confirming to IS 8112

3. Maximum nominal size of aggregates: $20 \mathrm{~mm}$

4. Maximum water cement ratio: 0.55

5. Workability: $75 \mathrm{~mm}$ (slump)

6. Exposure condition: Mild

7. Degree of supervision: Good

8. Type of aggregate: Crushed angular aggregate

9. Chemical admixture: not used

\section{Step 2:-Test Data For Materials:-}

1. Cement used: OPC 43 grade confirming to IS 8112

2. Specific gravity of cement: 3.15

3. Specific gravity of

Coarse aggregate: 2.68

Fine aggregate: 2.65

4. Water absorption

Coarse aggregate: 0.6 percent

Fine aggregate: 1.0 percent

5. Free (surface) moisture

Coarse aggregate: Nil (absorbed moisture full)

Fine aggregate: Nil

6. Sieve analysis

Coarse aggregate: Conforming to Table 2 of IS: 383

Fine aggregate: Conforming to Zone II of IS: 383

\section{Step 3 Target Strength For Mix Proportioning:-}

$\mathrm{f}_{\mathrm{ck}}=\mathrm{f}_{\mathrm{ck}}+1.65 \mathrm{~s}$ Where $\mathrm{f}_{\mathrm{ck}}=$ Target average compressive strength at 28 days,

$\mathrm{f}_{\mathrm{ck}}=$ Characteristic compressive strength at 28 days,

$\mathrm{s}=$ Standard deviation

From Table 1 standard deviation, $\mathrm{s}=4 \mathrm{~N} / \mathrm{mm}^{2}$

Therefore target strength $=20+1.65 \times 4=26.60 \mathrm{~N} / \mathrm{mm}^{2}$

\section{Step 4 Selection Of Water Cement Ratio:-}

From Table 5 of IS: 456-2000, maximum water cement ratio $=0.55$ (Mild exposure)

Based on experience adopt water cement ratio as 0.50

$0.5<0.55$, hence ok 
Step 5 selection of water content:-

From Table-2, maximum water content $=186$ liters

Estimated water content for $75 \mathrm{~mm}$ slump $=186+3 / 100 \times 186=191.6$ liters

\section{Step 6 calculation of cement content:-}

Water cement ratio $=0.50$

Cement content $=191.6 / 0.5=383 \mathrm{~kg} / \mathrm{m}^{3}$

From Table 5 of IS: 456 , minimum cement content for mild exposure condition $=300 \mathrm{~kg} / \mathrm{m}^{3}$

Hence OK

\section{Step 7 proportion of volume of coarse aggregate and fine aggregate content:-}

From Table 3, volume of coarse aggregate corresponding to $20 \mathrm{~mm}$ size aggregate and fine aggregate (Zone II) for water-cement ratio of $0.50=0.62$. Aggregates are assumed to be in SSD.

\section{Step 8 mix calculations:-}

The mix calculations per unit volume of concrete shall be as follows:-

1. Volume of concrete $=1 \mathrm{~m}^{3}$

2. Volume of cement $=$ Mass of cement/specific gravity of cement $* 1000$

$=[383.16 / 3.15] \times[1 / 1000]=0.122 \mathrm{~m}^{3}$

3. Volume of water $=[192 / 1] \times[1 / 1000]=0.192 \mathrm{~m}^{3}$

4. Volume of all in aggregates $(e)=a-(b+c)$

$=1-(0.122+0.192)=0.686 \mathrm{~m} 3$

5. Volume of coarse aggregates $=\mathrm{e} \times \mathrm{V}$ Volume of CA $\mathrm{x}$ specific gravity of CA $=0.686 \times 0.6 \times 2.68 \times 1000=1103 \mathrm{~kg}$

6. Volume of fine aggregates $=\mathrm{e} \times$ Volume of FA $\mathrm{x}$ specific gravity of FA $=0.686 \times 0.4 \times 2.65 \times 1000=727 \mathrm{~kg}$

Mix proportion:-

Table 1:- Mix Proportions.

\begin{tabular}{|l|l|l|l|}
\hline Cement & Water & Fine Aggregate & Coarse Aggregate \\
\hline 383 & 191.6 & 727 & 1103 \\
\hline 1 & 0.50 & 1.89 & 2.88 \\
\hline
\end{tabular}

Materials required for a batch of $\mathrm{M20}$ grade concrete:-

Step 1 volume calculations:-

Volume of 1 cube $=3.375 \times 10^{-3} \mathrm{~m}^{3}$

Volume of 1 cylinder $=5.30 \times 10^{-3} \mathrm{~m}^{3}$

Volume of 1 beam $=50 \times 10^{-3} \mathrm{~m}^{3}$

Total volume to be filled with concrete $=958.20 \times 10-{ }^{3} \mathrm{~m}^{3}$

Step 2 quantity calculations:-

Cement required $=958.20 \times 10^{-3} \times 383=366.99 \mathrm{~kg}$

Fine Aggregate $=958.20 \times 10^{-3} \times 72=696.61 \mathrm{~kg}$

Coarse Aggregate $=958.20 \times 10^{3} \times 1103=1056.9 \mathrm{~kg}$

Water required $=0.50 \times$ cement content

$$
\begin{aligned}
& =0.50 \times 383 \\
& =183.49 \text { liter }
\end{aligned}
$$

Casting of specimens:-

The materials were weighed accurately using a digital weighing instrument. For plain concrete, fine aggregates, coarse aggregate, cement, water were added to the mixture machine and mixed thoroughly for three minutes. Steel fibres were sprinkled randomly inside the mixture after thorough mixing of the ingredients of concrete so that homogenous mix is formed. For preparing the specimen tensile and flexure strength permanent steel moulds were used. Before mixing the concrete the moulds were kept ready. The sides and the bottom of the all the mould were properly oiled for easy demoulding. 
Table 2:- Different types of Specimen.

\begin{tabular}{|l|l|l|}
\hline \multicolumn{2}{|c|}{ Specimen Mould } & Dimension \\
\hline 1 & Cylinder & $150 X 300 \mathrm{~mm}$ \\
\hline 2 & Beam & $500 X 100 X 100 \mathrm{~mm}$ \\
\hline
\end{tabular}

\section{Curing:-}

Curing is the process of preventing the loss of moisture from concrete while maintaining a satisfactory temperature. More elaborately curing is defined as process of maintaining satisfactory moisture content and favorable temperature in concrete during the period immediately following placement, so that hydration of cement may continue until the desired properties are developed to a sufficient degree to meet the requirement at service.After casting the moulded specimens are stored in the laboratory and at a room temperature for 24 hours from the time at addition of water to dry ingredients. After this period the specimens are removed from the moulds immediately submerged in clean and fresh water. The specimens are cured for 28 days in the present work.

\section{Tests on hardened concrete:- Split tensile test:-}

This test was conducted as per IS: 5816-1970. The cylinders of standard size $150 \mathrm{~mm}$ diameter and $300 \mathrm{~mm}$ height was placed on the UTM, with the diameter horizontal. At the top a strip of steel was placed to avoid the crushing of concrete specimen at the points where the bearing surface of the compression testing machine and the cylinder specimen meets.

The Split Tensile Strength $\left(\mathrm{T}_{\mathrm{sp}}\right)=2 \mathrm{P} / \pi \mathrm{dl} \mathrm{N} / \mathrm{mm}^{2}$

The test is carried out by placing a cylindrical specimen horizontally between the loading surfaces of a compression testing machine and the load is applied until failure of the cylinder, along the vertical diameter. When the load is applied along the generated an element on the vertical diameter of the cylinder is subjected to a vertical compressive stress. In order to determine the split tensile strength of various concretes test was conducted as per IS: 5816-1999.

A total number of 24 cylindrical specimens were cast and after 28 days of curing, they were tested in a compression testing machine by loading it on the longitudinal direction

\section{Flexural strength test:-}

The most common concrete structure subjected to flexure is a highway or airway pavement and strength of concrete for pavements is commonly evaluated by means of bending tests. When concrete is subjected to bending, then tensile and compressive stresses and in many cases direct shear stresses are developed. When fibre reinforced concrete and composite beams are loaded in pure bending, then the tensile strains develop. The load at first crack would increase with respect to steel fibre reinforced concrete due to crack arresting mechanism of the closely spaced fibres. After the concrete matrix cracks, the fibres continue to take higher load which is provided. Thus the ultimate flexural strength is increased. Test specimens of beam size $100 \mathrm{~mm} \times 100 \mathrm{~mm} \times 500 \mathrm{~mm}$ were prepared for testing the flexural strength of steel fibre reinforced concrete and replacement of cement with marble dust in different percentages. The beam moulds containing the test specimens were placed in moist air (at least $90 \%$ relative humidity) and a temperature of $27^{0} \pm 2^{0} \mathrm{C}$ for 24 hours hour from the time of addition of water to the dry ingredients. After this the specimens were removed from the moulds and placed in clean fresh water at a temperature of $27^{0} \pm 2^{0} \mathrm{C}$ for the remaining curing period. After 28 days of curing the specimens were tested in flexure on a Universal Testing Machine. Loads were applied at the one third points at a constant rate of $30 \mathrm{~kg} / \mathrm{minute}$. The distance between the centres of two rollers was kept $20 \mathrm{~cm}$. If the fracture occurred within the central one-third of the beam, the flexural strength was calculated on the basis of ordinary elastic theory using the following equations:

$\mathrm{F}_{\mathrm{b}}=\mathrm{PL} / \mathrm{BD}^{2}$, when ' $\mathrm{a}$ ' is greater than $20 \mathrm{~cm}$ for $15 \mathrm{~cm}$ specimen

$\mathrm{F}_{\mathrm{b}}=3 \mathrm{~Pa} / \mathrm{BD}^{2}$, when ' $\mathrm{a}$ ' is less than $20 \mathrm{~cm}$ but greater than $17 \mathrm{~cm}$ for $15 \mathrm{~cm}$ specimen

Where,

$F_{b}=$ Flexural Strength of the specimen in N/mm ${ }^{2}$

$\mathrm{B}=$ Width of the specimen $(=100 \mathrm{~mm})$

$\mathrm{D}=$ Depth of the specimen $(=100 \mathrm{~mm})$

$\mathrm{L}=$ Span of the specimen $(=500 \mathrm{~mm})$

$\mathrm{P}=$ Maximum load in Newton $(\mathrm{N})$ applied to the specimen

$\mathrm{a}=$ Distance $\mathrm{b} / \mathrm{w}$ the line of fracture and nearer support, measured on the centre line of the tensile side of the specimen in $\mathrm{cm}$, shall be calculated to the nearest $0.5 \mathrm{~kg} / \mathrm{cm} 2$. 
If ' $\mathrm{a}$ ' is less than $17 \mathrm{~cm}$ the results of a test shall be discarded. Test results of flexural test at the age of 28 days curing. The flexural strength results of concrete mix are also shown graphically.

\section{Result:-}

The results obtained during the experiment are provided in terms of charts and tables . $7 \& 28$ days Flexure and split tensile strength of steel fibre reinforced concrete are compared with each other for a clearer representation of how percentage of steel fibres added affects the strength of concrete.

\section{Days Tensile Strength:-}

Design Mix: 1:1.89:2.88 \& w/c ratio $=0.50$

Table 3:- Result of 7 days Split Tensile Strength.

\begin{tabular}{|l|l|l|l|l|l|}
\hline Sample & $1^{\text {st }}$ & ${ }_{2}$ nd & $3^{\text {rd }}$ & Average & Tensile Strength \\
\hline & Reading & reading & Reading & reading & $\left(\mathrm{N} / \mathrm{mm}^{2}\right)$ \\
\hline & & & & & \\
\hline S-0 & 75 & 80 & 80 & 80 & 1.14 \\
\hline & & & & & \\
\hline S-1 & 120 & 122 & 120 & 120 & 1.7 \\
\hline & & & & & 2.1 \\
\hline & 145 & 138 & 137 & 140 & \\
\hline S-3 & 132 & 130 & 130 & 130 & 1.84 \\
\hline & & & & & \\
\hline
\end{tabular}

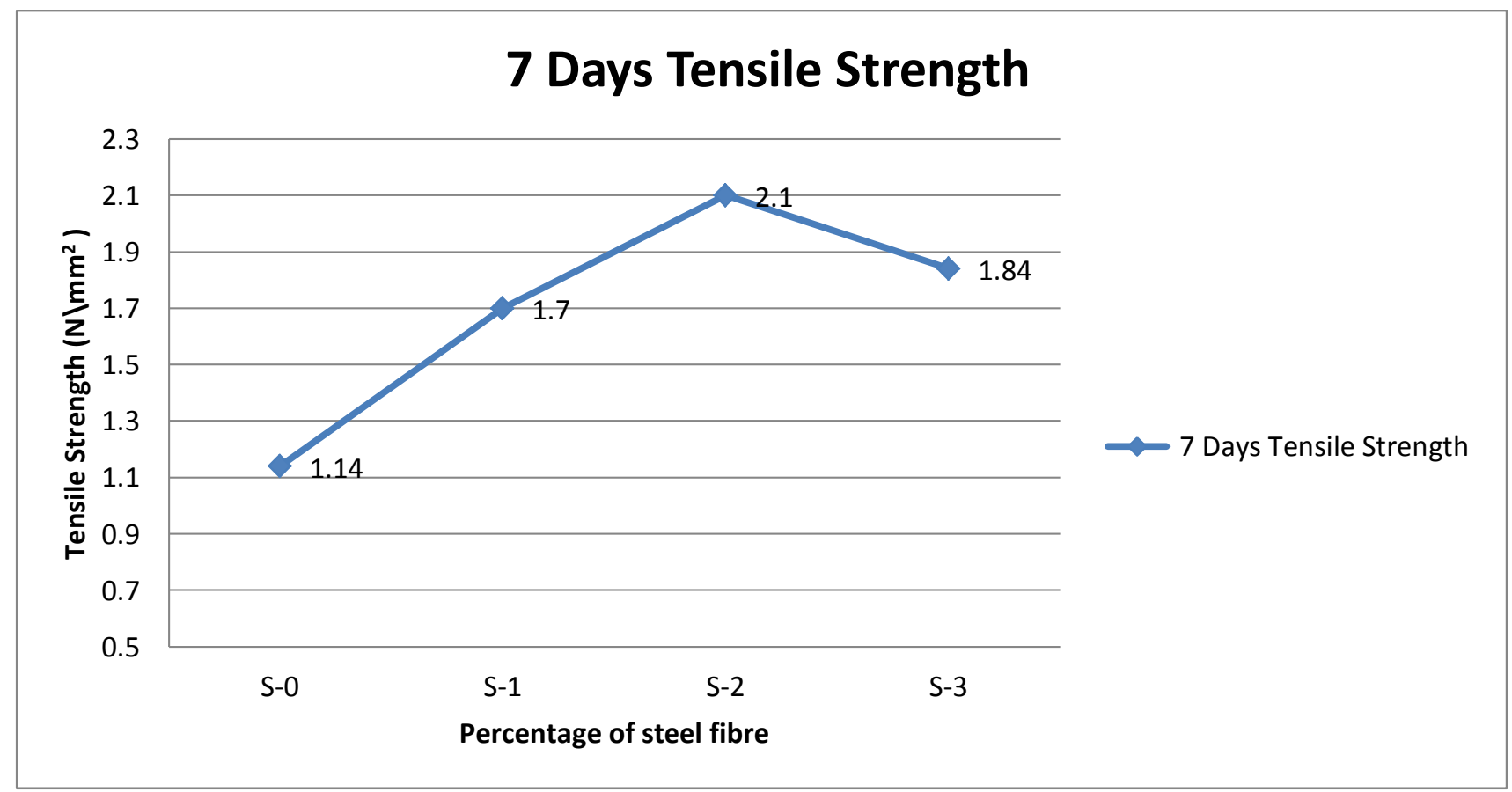

Figure 1:- Split Tensile Strength for 7 days with different $\%$ of steel fibre.

28 Days Tensile Strength:-

Design Mix: 1:1.89:2.88 \& w/c ratio $=0.50$ 
Table 4:- Result of 28 days Split Tensile Strength.

\begin{tabular}{|c|c|c|c|c|c|}
\hline Sample & ${ }_{1} \mathrm{st}$ & $2^{\text {nd }}$ & $3^{\text {rd }}$ & Average & Tensile Strength \\
\hline & reading & Reading & Reading & reading & $\left(\mathrm{N} / \mathrm{mm}^{2}\right)$ \\
\hline S-0 & 150 & 140 & 160 & 150 & 2.12 \\
\hline S-1 & 230 & 230 & 232 & 230 & 3.253 \\
\hline S-2 & 255 & 250 & 245 & 250 & 3.543 \\
\hline S-3 & 210 & 208 & 210 & 210 & 2.976 \\
\hline
\end{tabular}

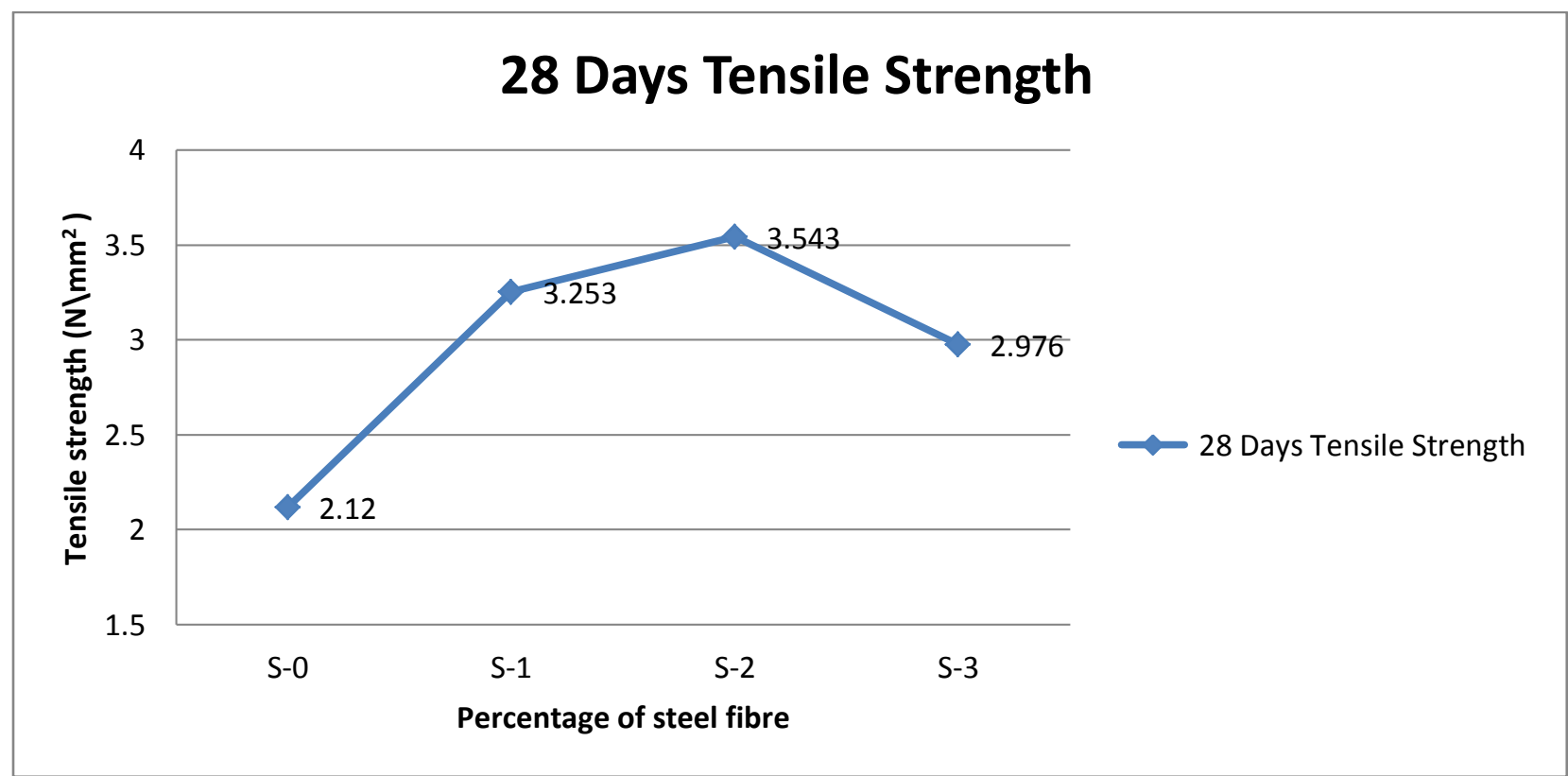

Figure 2:- Split Tensile Strength for 28 days with different $\%$ of steel fibre.

28 Days Flexural Strength:-

Design Mix: 1:1.89:2.88 \& w/c ratio $=0.50$

Table 5:-Result of 28 days Flexural Strength.

\begin{tabular}{|l|l|l|l|l|l|}
\hline Sample & ${ }_{1}$ st & ${ }_{2}$ nd & ${ }_{3}^{\text {rd }}$ & Average & Flexural Strength \\
\hline & reading & reading & Reading & reading & $\left(\mathrm{N} / \mathrm{mm}^{2}\right)$ \\
\hline S-0 & 12 & 12 & 14 & 12 & 3.6 \\
\hline S-1 & 15 & 15 & 16 & 15.5 & 4.65 \\
\hline S-2 & 18.5 & 19 & 19.5 & 19 & 5.7 \\
\hline S-3 & 21 & 21 & 20.8 & 21 & 6.3 \\
\hline S-4 & 17 & 18 & 16 & 17 & 5.1 \\
\hline
\end{tabular}




\section{8 days Flexural Strength}

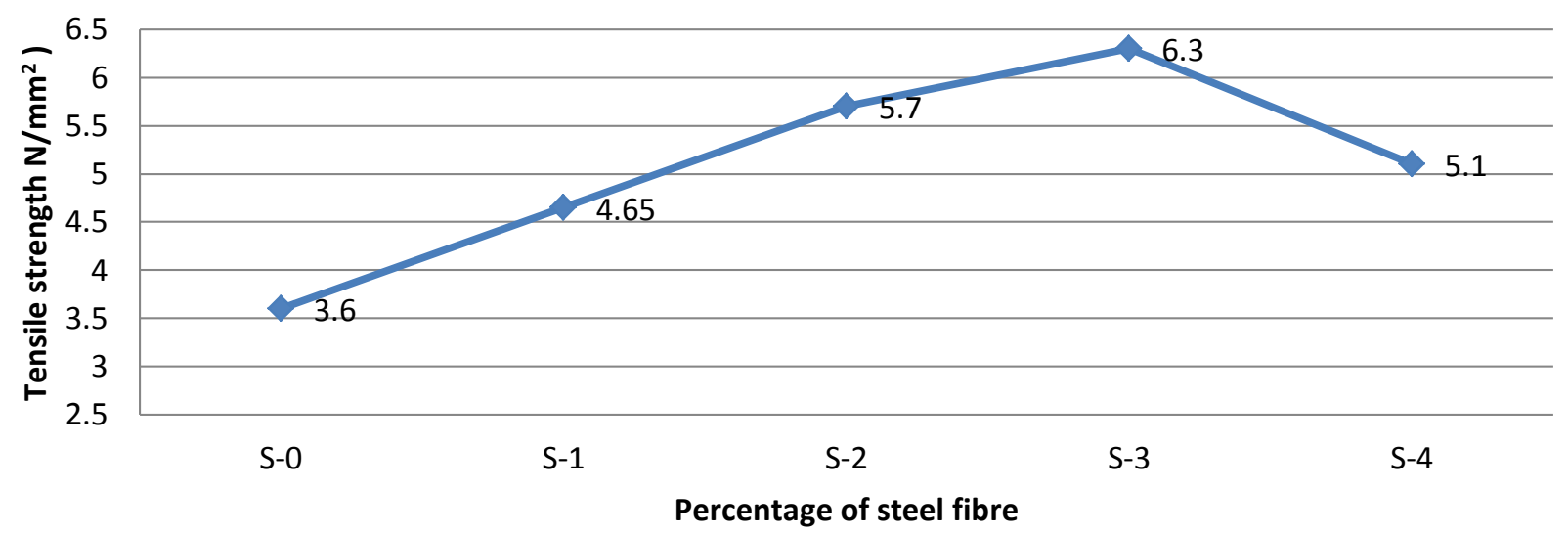

Figure 3:- Flexural strength with different $\%$ of steel fibre

7 Days vs. 28 Days Tensile Strength Comparison:-

Design Mix: 1:1.89:2.88 \& w/c ratio $=0.50$

Table 6:- Comparison of 7 and 28 days Split tensile Strength.

\begin{tabular}{|l|l|l|}
\hline Sample & 7 Days Tensile & 28 Days Tensile \\
\hline & Strength $\left(\mathrm{N} / \mathrm{mm}^{2}\right)$ & Strength $\left(\mathrm{N} / \mathrm{mm}^{2}\right)$ \\
\hline S-0 & 1.14 & 2.12 \\
\hline S-1 & 1.7 & 3.253 \\
\hline S-2 & 2.1 & 3.543 \\
\hline S-3 & 1.84 & 2.976 \\
\hline
\end{tabular}

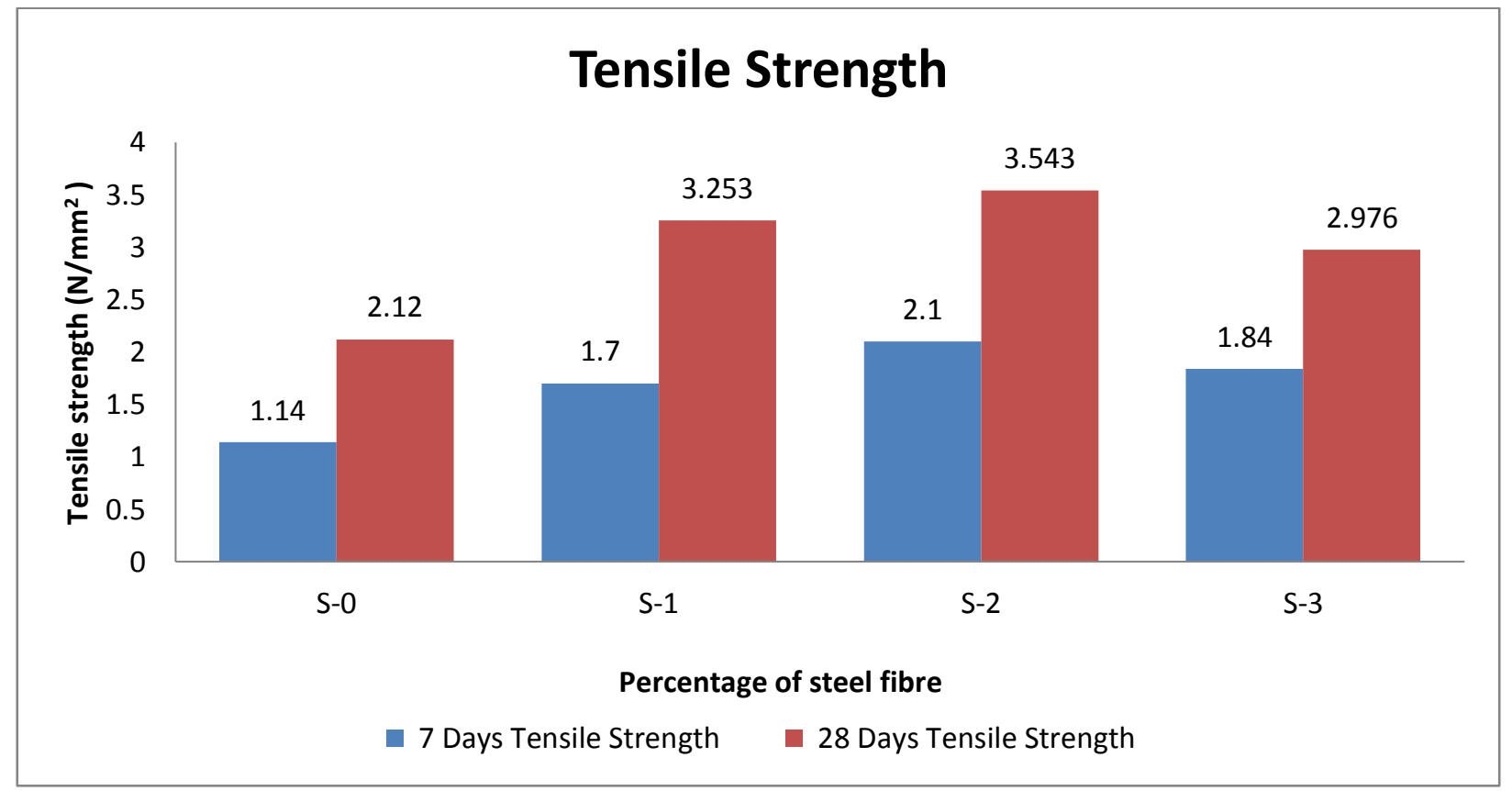

Figure 4:- Bar Chart of Variation 7 days and 28 days Split tensile Strength with different \% steel fibre

7 Days vs. 28 Days Tensile Strength Comparison:-

Design Mix: 1:1.89:2.88 \& w/c ratio $=0.50$ 


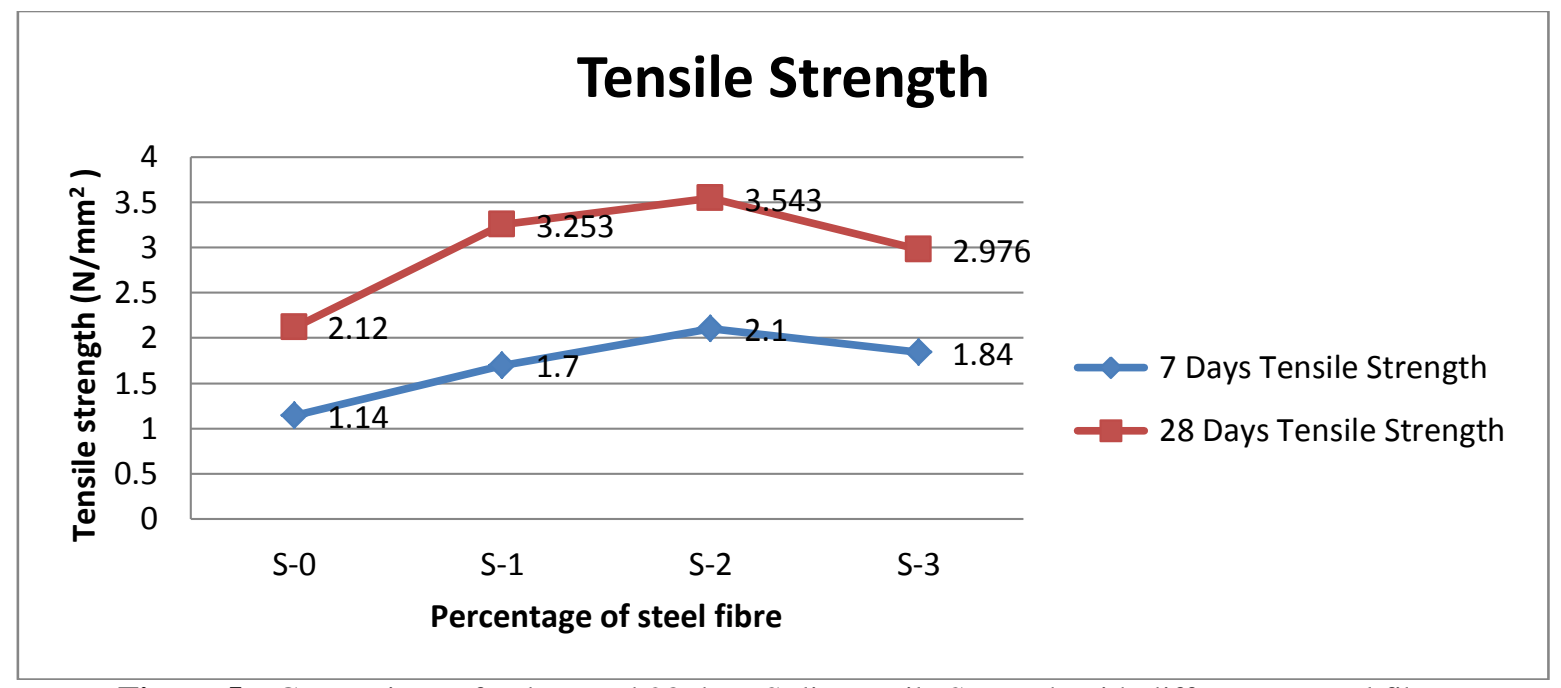

Figure 5:- Comparison of 7 days and 28 days Split Tensile Strength with different \% steel fibre

\section{Conclusion:-}

1. The strength of the steel fibre reinforced concrete depends largely on the quantity of fibres added to it. The increase in the volume of fibres, increase approximately linearly with the tensile strength and toughness of the composite.

2. Use of higher percentage of fibre is likely to cause segregation and hardness of concrete and mortar and also the workability of concrete is greatly reduced.

3. The $7 \& 28$ days the tensile strength of the concrete increases linearly with the increase in amount of steel added to it, but to a maximum of $1 \%$ steel fibre inclusion. After that it decreases. So the optimum percentage of steel fibre inclusion is $1 \%$ by volume of the concrete mix.

4. The flexural strength increases with the increase in steel fibre inclusion but to a maximum of $1.5 \%$ by volume of concrete mix. After that the flexural strength decreases

Table 7:-Variation of different parameters of steel fibre reinforced concrete

\begin{tabular}{|l|l|l|l|l|}
\hline $\begin{array}{l}\text { Parameter } \\
(28 \text { Days-N/mm }\end{array}$ & PCC & $\begin{array}{l}\text { Optimum \% Of } \\
\text { Steel fibre inclusion }\end{array}$ & $\begin{array}{l}\text { SteelFibre Reinforced } \\
\text { Concrete(SFRC) }\end{array}$ & $\begin{array}{l}\% \text { increase in } \\
\text { Strength }\end{array}$ \\
\hline $\begin{array}{l}\text { Tensile } \\
\text { Strength }\end{array}$ & 2.12 & $1 \%$ & 3.543 & $67.12 \%$ \\
\hline $\begin{array}{l}\text { Flexure } \\
\text { Strength }\end{array}$ & 3.6 & $1.5 \%$ & 6.3 & $75 \%$ \\
\hline
\end{tabular}

\section{References:-}

1. ASTM A820-97 (1997) "Standard Specification for steel fibres for reinforced concrete" American society for testing and materials

2. ACI 506.1R.84 (1984) "State of the art report on fibre reinforced shotcrete" ACI committee report, American Concrete Institute

3. "Measurement of Fibre Reinforced Concrete," ACI Committee 544, American Concrete Institute Materials Journal, Vol. 85, No. 6, pp. 583-593, American Concrete Institute 1988.

4. I.S: 10262-2009 "Indian code for recommended guidelines for concrete mix design".

5. I.S 456-2000 "Indian code of practice for plain and reinforced concrete (Fourth Revision)".

6. I.S 516-1959 "Indian code for method of tests for concrete".

7. Henager, C.H. (1977) "Steel Fibrous, Ductile Concrete Joint for Seismic Resistant Structures." Reinforced Concrete Structures in Seismic Zones, SP 53-14, American Concrete Institute, Detroit, pp. 371-386.

8. Jindal, R. and Hassan, K. (1982) "Behaviour of Steel Fibre Reinforced Concrete Beam-Column Connections." Fibre Reinforced International Symposium, SP-81, American Concrete Institute, Detroit, pp. 107-123.

9. Krishnamoorthy, T.S. Bharatkumar, B.H. Balasubramanian, K. and Gopalakrishnan, S. (February 2000) "Investigation on durability characteristics of SFRC" Indian Concrete Journal page 94-98 
10. Parameswaran, V.S. (October 1996) "Research and applications of FRC in Indian scenario" Indian concrete journal,, pp.553-557

11. P.Srinivasalu, N.Lakshmanan, K.Muthumani, B.Sivarama Sarma (1987) "Dynamic behaviour of fibre reinforced concrete" proceedings of the international symposium on Fibre Reinforced Concrete International Symposium, volume I, chapter II, pp 2-8

12. Sivarama Sarma, B. (1997), "Investigations on laced reinforced concrete beams with normal and fibre reinforced concrete under monolithic and cyclic loading" Ph.D Thesis, IIT, Madras.

13. Shetty, M.S. (2005), "Concrete Technology theory and practice", (First edition-1982) S.Chand and Company, New Delhi.

14. Soroushian, P. and Bayasi, Z. (December 1991) "Strength and Ductility of Steel Fibre Reinforced Concrete under Bearing Pressure." Magazine of Concrete Research, p p.243-248.

15. Swamy, R.N. (October 1996) "Fibre reinforced concrete: Prospect and challenges, Indian Concrete Journal, pp 510-517. 